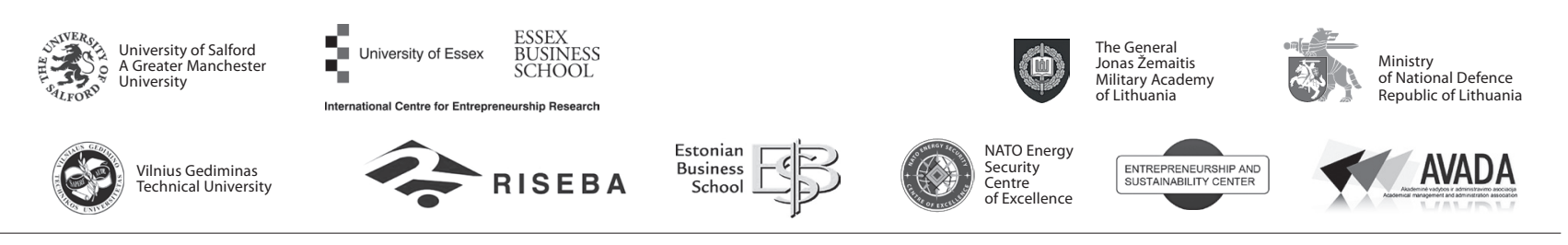

\author{
JOURNAL OF SECURITY AND SUSTAINABILITY ISSUES \\ ISSN 2029-7017 print/ISSN 2029-7025 online \\ 2018 June Volume 7 Number 4 \\ https://doi.org/10.9770/jssi.2018.7.4(15)
}

\title{
BOARD DIVERSITY, RISK AND SUSTAINABILITY OF BANK PERFORMANCE: EVIDENCE FROM INDIA
}

\author{
Ascariena Rafinda ${ }^{a}$, Ascaryan Rafinda ${ }^{b}$, Rini Setyo Witiastutia \\ Agus Suroso $^{b}$, Irwan Trinugrohoc \\ ${ }^{a}$ Faculty of Economics, Universitas Negeri Semarang, Indonesia \\ ${ }^{b}$ Faculty of Economic and Business, Universitas Jenderal Soedirman, Indonesia \\ ${ }^{c}$ Faculty of Economic and Business, Universitas Sebelas Maret, Indonesia \\ E-mail: irwan.trinugroho@gmail.com
}

Received 20 June 20 2017; accepted 10 March 2018

\begin{abstract}
This paper finds out the impact of a board diversity in terms of nationality and gender diversity on sustainability of bank performance and risk in Indian Banking and Financial Industry over the period of $2011-2015$. Our results show that the presence of foreign directors is found to lead into a worse firm performance, but no significant relationship is found for the existence of women directors on bank performance. The nationality and gender diversity are found to have positive and significant impact to the bank risk. By looking at this, the regulation in India should pay more attention to the inclusion of foreign and women directors in their board as the improvement of corporate governance in emerging markets. Some contributions are made in this paper, which are first, this study gives new perspective in India as emerging market especially in financial industry, while most of the studies are conducted in U.S. and Europe. Most of the studies in India regarding the impact of board diversity to bank performance are conducted in all sectors, not specifically on the banking and financial industry and there is not any research which is conducted to find the impact on bank risk. However, some limitations are found. First, limited sample as it only covers 22 banks and financial industries due to lack of data on board diversities. Second, only 2 diversities are examined, while there are more diversities could be observed, such as age, education, experience.
\end{abstract}

Keywords: board diversity, nationality diversity, gender diversity, bank performance, bank risk, sustainability, India

Reference to this paper should be made as follows: Rafinda, A.; Rafinda, A.; Witiastuti, R.S.; Suroso, A.; Trinugroho, I. 2018. Board diversity, risk and sustainability of bank performance: evidence from India, Journal of Security and Sustainability Issues 7(4): 793-806. https://doi.org/10.9770/jssi.2018.7.4(15)

JEL Classification: G30, G21, J16

\section{Introduction}

There have been wide-ranging discussions about the impact of a board diversity in terms of nationality, gender, age and tenure on firm performance and value, risk, and the corporate governance. Masulis et al. (2012) highlight the two essential roles of board directors : to recruit the managers, and to give suggestions to CEO regarding the firm's plan. From the aforementioned types of a board's diversities, this study will focus on both nationality and gender diversity in the banking industry. There are number of reasons why nationality diversity should be focused upon. First, as the board directors influence the firm operations, the nationality of the board directors may affect the interest of the shareholder and the value of the decision made by foreign independent directors (FIDs) which result in the overall performance of the firm (Estélyi et al., 2016). Second, as mentioned by Estélyi et al. (2016), there are only a few studies regarding the nationality diversity on board directors (Ma- 
sulis et al.,2012; Oxelheim and Randøy, 2013; Miletkov et al., 2014). For the gender diversity, some countries such as Norway, Spain, France, Italy, India and Malaysia have started to urge companies to have at least one woman in their boards in recent years (Schwizer, et al., 2012). There have been a lot of studies regarding the presence of women directors on firms, however, there is still a lack of studies related to women directors in banking sectors. The research regarding the presence of women directors is considered to be important for two reasons. First, women have different characteristics from men in relation to the financial and board assessment in which women appear to be more risk-averse compared to men and has ficcerent perception of other management facets (Sunden and Surette, 1998; Agnew et al., 2003; Rosha, Lace, 2018; Raudeliūnienè et al. 2018; Giedraitis et al., 2017; Luhn et al., 2017; Sokół, Figurska, 2017; Davydenko et al., 2017). The second, women directors are better at handling information under uncertanties, which refer to the restricted knowledge of finance that is owned by the board directors (Rost and Osterloh, 2010). Further, this research will focus separately on the banking and financial industry for some reasons. De Andrés and Vallelado (2008) mention that the directors in banking industry are related to the great informational asymmetries and restricted competition because of the banking complexities. As decisions taken by banks have substantial impact to the economy (Pathan and Faff, 2013), the board in banking sectors have an important role in stabilizing the economy of a country. Pathan and Faff (2013) explain that the corporate governance of the banking sector influences the nonfinancial companies that later will impact the entire economy. Additionally, the activities of banks which relate to the private information of their customers lead to more difficulties in assessing the risk of bank (Hagendorff, Collins, and Keasey, 2007).

The first concern in this study is to find out the impact of the nationality and gender diversity to the firm's performance in an accounting-based measurement that reflects the profitabilty of the companies. Previous literatures capture both positive and negative impacts of having foreign independent directors (FIDs) and female directors to the firm success. FIDs provide more knowledge about global business resulting in better performance of the company; however, it also causes additional cost and time since they have difficulties to do on-site visit (Masulis et al., 2012). In the banking industry, existing studies draw attention to the negative impacts of the presence of foreign directors to the banking accomplishment in Europe, Turkey and Indonesia (Garcia-Meca et al., 2015; Kilic, 2015; Setiyono and Tarazi, 2014). In contrast, there are mixed findings in the studies relating to the inclusion of female directors. Kilic (2015) finds a negative relationship between this and the performance of the banking industry in Turkey. Setiyono and Tarazi (2014) show a positive relationship in Indonesia. Wachudi and Mboya (2012) show no relationship in Kenya.

Furthermore, this study is focused on the effect of nationality and gender diversity to the firm's risk taking. Local firms in countries with high level of risk takers tend to take more risks, specifically in sectors with vague information such as finance (Mihet, 2012). The presence of foreign directors is found to increase the firm's risk in Indonesian banking industry (Setiyono and Tarazi, 2014). For the gender diversity, earlier studies find mixed results on the existence of female directors to the risk taking. The positive relationship is found due to the lack of experience by women directors in German banking sector (Berger et al.,2014). In contrast, as most of women are risk averse, they tend to take less risk to avoid failure (Barber and Odean, 2001; Jianakoplos and Bernasek, 1998; Mateos de Cabo et al., 2012). The aim of this study is to measure the impact of board diversity in terms of nationality and gender on bank performance and risk in India. India is chosen to be the subject of this study for three reasons. First, different from other emerging markets, India have actively participated in stock markets since 1875 even with limited practice of corporate governance (Jindal and Jaiswall, 2015). Second, Clause 149 was introduced in India to regulate the corporate governance of listed firms. One of the enactment of Clause 149 states that the listed companies in India have to present at least one female director in their board composition. Third, it is interesting to examine how the board diversity in India affects the bank performance and risk taking as it is the second largest populated country in the world. This study makes four contributions to the existing literature. First, previous researches in this topic are mainly completed in Europe and the U.S.; thus, this research will give new perspective of how board diversity affects the bank performance and risk in emerging market: India. Second, most researches are mainly conducted in all firms excluding the financial ones; therefore, this study will provide new insights how it impacts on financial companies. Financial firms have a unique characteristic as a financial intermediary institution and external sources of financing for 
other firms (Włodarczyk et al., 2018). Banks play important role in a country’s economy especially in emerging economies (Trinugroho et al., 2014; Jurevičienè and Skvarciany, 2016). Third, to our knowledge, there are not a lot of researches conducted in the impact of board diversity to the bank performance in the India as most of the existing studies are conducted in all sectors, not specifically on banking and financial sectors. Last, most of the studies in India examine the relation between board diversity and performance. However, there has been no research conducted to see the effect this has on risk, therefore, this study will contribute to this point.

\section{Literature Review}

\subsection{Theoretical Framework}

Previous researches on corporate governance that relates to the board diversity are built on some theories: agency theory, power, and resource dependent. Agency theory describes the relationship between the principals (shareholders) and the agents (managers). The problem arises when the interest of shareholders is not aligned with the interest of managers (agency problems). Jensen and Meckling (1976) describe that board of directors acts to ensure that the actions taken by managers are in line with the shareholders' interest; thus, agency problems can be prevented. There are mixed findings on the effect of board diversity on this. Foreign boards may understand the complexity of a situation in a business and thus may give indications to the investors and firm (Goodstein et al., 1994; Wiersema and Bantel, 1992). Estélyi, et al. (2016) add to this by saying that more diverse directors offer various knowledge, skill and perception in how to deal with new investments. The value of the decisions taken by the diverse board is also considered to be higher and more ground-breaking (Maznevski, 1994). However, there are some drawbacks in having FIDs on a firm. Masulis et al. (2012) find that the performance of the company gets worse at the absence of the business from the FIDs home countries. Miletkov et al. (2014) also show that the firm's performance is worse when the foreign boards are located in the countries with the top level in legal. One of the governance mechanisms to overcome agency problems is the board directors and compensation: One way for principals to obtain more information about the company is by increasing the compensation of the CEOs to make them feel that they have the ownership over the firm (Davis, J.H. et al., 1997). One theory relating to this compensation is power theory which means maximasing the CEOs' salary so that they use their power to make impact on executive compensation. Resource dependent theory states that board directors are resources that may affect the actions taken by the company (Johnson et al., 1996; Hillman et al., 2000). Board directors are seen as (1) the resource to the environment, (2) external resources, and (3) financial resources that may maximise firm value. As the first point, Lynall et al. (2003) see board directors' actions as resources that decrease the environmental ambiguity and diminish operation expenses related to the environmental independency by relating the firm to the outside environment. Later, as the second point, board directors are considered to provide knowledge, skills, ideas, and links to key constituencies (Hillman et al., 2000). As the last point, they also bring financial resources to the firm. There is a tendency of the firm with financial problems to assign the boards from financial institutions that will build new chance for them from having collaboration in the future (Mizruchi, et al., 1988).

Overall, these theories conclude that the election of board directors is vital due to their role in making sure that the objectives between managers and shareholders are aligned, therefore they can avoid the agency problems. The agency problems can be mitigated by the compensation to the executives to create the sense of ownership to the corporation. Furhermore, board directors are seen as the resources to the decisions taken by the company that will influence the investors' perspective to the firms. The way investors see the company will affect their decision to invest in the future that will certainly impact the enterprise value.

\subsection{Effects of Board Diversity on Bank Performance}

There are mixed findings regarding the impact of nationality diversity on the firm performance. Having foreign directors may add value to the firm (Oxelheim and Randøy, 2003). Masulis et al. (2012) show that having foreign directors will enlarge the quality of the firm through their information and recommendations in the international industry. Hence, it will open the opportunity for the firm to expand their business to a global level 
(Adams, et al., 2010). Not only to enlarge its markets, the firm may also invite new investors as FIDs provide innovative thinking and capability to the firm (Garcia-Meca et al., 2015). However, there are some negative impacts by employing FIDs. The distance is the first problem that comes up where they get difficulties to do on-site visit and to come to meetings (Masulis et al., 2012). This problem relates to the inability of FIDs to obtain the latest information about the firm operations (Masulis et al., 2012). Forbes and Miliken (1999) consider communication as one of the problems faced by FIDs which can result in conflicts among members of the firm. This finding is strengthen by Ruigrok, W. et al. (2007) discovering that nationality-diverse boards are likely to be correlated with conflicts and misunderstandings. There has been a wide-ranging discussions regarding the impact of gender diversity to the firm performance. Using the measurement of ROA and ROI, Erhardt, Werbel, and Shrader (2003) find that the presence of gender diversity on board leads to a better corporate's performance. In contrast, Adams and Ferreira (2009) find a negative relationship between gender board diversity on a firm's performance, even though women boards are found to extract more monitoring. Specifically in developing countries, Kusumastuti et al. (2007) find that there is no significant impact caused by the female board directors to the firm's performance in Indonesia measured by Tobin's Q. However, Darmadi (2011) find that there is a negative relationship between the presence of women directors to the firm performance in Indonesia in the measure of ROA and Tobin's Q. In Thailand's firms, Sitthipongpanich and Polsiri (2013) find that there is no significant relationship between gender diversity and the firm's value. Similarly, in Malaysian companies, Marimuthu and Kolandaisamy (2009) also find that there is no significant impact of gender diversity to the firm financial performance.

However, those results may not be representative of the impact on banking industries because of the concerns stated previously in the introduction. Garcia-Meca et al. (2015) explains that nationality diversity of the board directors prevent the financial performance of European banking industries. While in the case of emerging markets, Kilic, M. (2015) find that the presence of nationality diversity of board directors in Turkey leads to worse banking performance. In the case of Indonesia, Setiyono and Tarazi (2014) find that there is negative relationship between nationality diversity of board directors to the performance of banks in Indonesia. Regarding the gender diversity, Kilic (2015) finds that the presence of gender diversity of board directors in Turkey leads to worse banking performance. In contrast, Setiyono and Tarazi (2014) find that there is positive relationship between gender diversity of board directors to the performance of bank in Indonesia. While in the case of Kenya, it is found that there is no significant relationship between gender diversity on board directors to the performance of bank (Wachudi and Mboya, 2012). On the whole, the existing literatures show mixed results of foreign directors to the firm's performance; however, most studies on the developed and developing countries (European countries, Indonesia, and Turkey) present the negative impact of the inclusion of FIDs. The negative impact presented in the emerging markets may be triggered by their unpreparedness (such as language and culture), which can also happen in India as a developing country. Therefore, the hypothesis regarding nationality diversity can be formulized as follows:

H1: There is a negative relationship between the presence of nationality diversity and bank performance in India

Regarding the gender diversity, the previous studies present both positive and negative impacts on the firm performance. Nevertheless, most studies argue that women directors are found to be more risk averse and less confident than male ones, leading them to make low-risk decisions. As the low risk decision is in line with low return, it may lead the company to be less attractive to the investors. Hence, the second hypothesis is formulated as follows:

H2: There is negative relationship between the presence of gender diversity and bank performance in India

\subsection{Effects of Board Diversity on Bank Risk}

There is still a lack of studies highlighting the effect of nationality diversity of board directors to the bank risk. Setiyono and Tarazi (2014) stating that the presence of FIDs in Indonesia banking sector increases the risk. Mihet (2012) examines the impact of culture to the risk taking and finds that local companies in countries with low level of ambiguity aversion tend to take more risk, especially in those sectors where the information are 
vague such as finance. Tse et al. (1998) also find that the culture of home country affects the way managers make decision. Later, Graham et al. (2010) show that ambiguity aversion as the cultural value influences the executives' decision making. Even though these previous studies are not conducted directly to examine the impact of nationality diversities of a board to the risk taking by firm, it may represent that the culture of the boards may affect the way they make decision in terms of risk. Gender diversity is measured by the presentation of women in board directors. Jianakoplos and Bernasek (1998) explain that as the level of risk aversion by women is higher than men, it may lead to the worse firm performance since the lower risk, the lower return that might be gained. In contrast, Berger et al. (2014) who focus on managers rather than non-executives directors find that as the number of women boards increases, the portfolio risk of the Germany banks also increases due to the less experience women have compared to male boards. In the field of banking and financial industries, Setiyono and Tarazi (2014) stating that the presence of FIDs in Indonesia banking sector increase the risk. Regarding the gender diversity, Berger et al. (2014) who focus on managers rather than non-executives directors find that as the number of women boards increases, the portfolio risk of the Germany banks also increases due to the less experience women have compared to male boards. To conclude, there is still lack of observations regarding the impact of having foreign directors to the firm's risk. Nonetheless, most studies show that the culture of their home country influences their risk tolerance in making decisions. The presence of nationality diversity indicates that the more cultures are found in a company, the more people may tolerate to others . By having higher tolerance to other cultures, the company might take more risk. Therefore, the hypothesis regarding the impact of nationality diversity to the firm's risk can be formulated as follows:

$H 3$ : There is positive relationship between the presence of nationality diversity to the risk taking in Indian banking industry

Literatures on gender diversity indicate mixed impact to the firm's risk. However, most studies present the negative effects of the existence of women directors to the firm's risk due to their characteristic as the risk averse. This negative relationship is also confirmed by the literature on non-financial enterprises and emerging markets, that might happen in India as one of the developing countries. Thus, the last hypothesis regarding the impact of gender diversity to risk taking is formulated as follows :

$H 4$ : There is negative relationship between the presence of gender diversity to the risk taking in Indian banking industry.

\section{Data And Methodology}

\subsection{Data}

Financial firms in India will be the subject of this analysis and the data will be obtained mainly from Bankscope, Annual Reports and Spencer Stuart. Spencer Stuart provides the data of board index for some countries, including India. As the data of board profiles in Spencer Stuart are limited, the data in this study are restricted to the data of financial firms presented in Spencer Stuart, comprising of 22 state banks and financial institutions. Further, this study will cover the period of 2011 - 2015 and a total of 110 observations. The data of the firm's performance and risk are obtained from Bankscope and calculated manually based on the formula presented in Table 1. When the data are missing from Bankscope, they are retrieved from the annual report of the banks and financial institutions.

\subsection{Methodology}

The objectives of this study are to examine the impact of nationality and gender diversity to the performance and risk taking on the Indian Banking and Financial Industry. Therefore, there will be two regression equations to be conducted in this research. 


\subsubsection{Impact of Board Diversity on Firm Performance}

There are 2 proxies to find the effect of board diversity on the firm's performance. Following the proxies used by Estélyi et al. (2016), Kilic, M. (2015), Nys et al. (2015) and Setiyono and Tarazi (2014), the first one is Return on Assets (ROA) and the second is Return on Equity (ROE) to examine the accounting profitability. ROA and ROE are defined as the dependent variables and board diversities that consist of nationality diversity and gender diversity are defined as the independent variables. The equations for Firm's ROA and Firm's ROE are followed :

$$
\begin{aligned}
& \text { Firm's } R O A=\beta_{0}+\beta_{1} \text { board diversity }+\beta_{2} \text { control variables }+\varepsilon \\
& \text { Firm's } R O E=\beta_{0}+\beta_{1} \text { board diversity }+\beta_{2} \text { control variables }+\varepsilon
\end{aligned}
$$

\subsubsection{Impact of Board's Diversity on Firm's Risk}

There are 4 proxies to determine the impact of the board's diversity to the bank's risk. Following the studies by Mihet, R. (2012) and Setiyono, B. and Tarazi, A. (2014), Trinugroho et al. (2017) the proxies used to examine the impact of board's diversity on risk by measuring standard deviation of ROA, standard deviation of ROE and Z-Score. Standard deviation of ROA (SDROA) and standard deviation of ROE (SDROE) represent the risk taken by a firm based on the variability of the firm's income. The volatility of ROA represents various kinds of risks, such as liquidity, leverage, and interest rate risk. The studies by Setiyono, B. and Tarazi, A. (2014) show that in measuring the standard deviation of ROA, ROA from the last three years is used as the calculation. However, in this study the standard deviation of ROA based on the ROA on the last four years is computed as it might not have any change in the last three years. The same method is also applied to the standard deviation of ROE. After standard deviation of ROA and ROE, later Z-Score is used to reflects the insolvency risk (Laeven and Levine 2009; Kanagaretnam et al. 2011). The higher the Z-Score means the better and the more steady the financial condition the company has (Mihet, R., 2012) because it represents the number of standard deviation that the company's losses might rise and lead the firm into bankruptcy since the number of capital decreases (De Nicolò, 2000). There are 2 ways to calculate the Z-Score: the first one is Z-Score (ZSA) to measure the asset's risks and Z-Score (ZSL) to measure the leverage risk. Further, SDROA, SDROE, ZSA and ZSL are defined as the dependent variables, while the independent variables and control variables are same as the measurement for the firm' performance. The equations for measuring the company's risk are as follows :

$$
\begin{aligned}
& \text { Firm's } S D R O A=\beta 0+\beta 1 \text { board diversity }+\beta 2 \text { control variables }+\varepsilon \\
& \text { Firm's } S D R O E=\beta 0+\beta 1 \text { board diversity }+\beta 2 \text { control variables }+\varepsilon \\
& \text { Firm's } Z S A=\beta 0+\beta 1 \text { board diversity }+\beta 2 \text { control variables }+\varepsilon \\
& \text { Firm's } Z S L=\beta 0+\beta 1 \text { board diversity }+\beta 2 \text { control variables }+\varepsilon
\end{aligned}
$$

\subsubsection{Control Variables}

Four control variables are applied as they may affect the performance and risk of the bank based on previous studies. Following the research by El Mehdi (2007), the firm size is expected to affect the performance of the firm. As the size of the bank becomes larger, it may reduce the bank's risk since they might a a better portfolio diversification. De Nicolo (2000) also explains that a bank may get an advantage of Too-Big-To-Fail as the bank size increases. The board size is also expected to affect the performance of the bank (de Andrés and Valelado, 2008). As the board size becomes smaller, this will allow the executives to stand for higher risks; therefore, the risk gets higher when the board is smaller (Wang, 2012). Ararat et al. (2010) also considers that board independence may affect the performance of a firm. Ashbaugh-Skaife et al. (2006) find that the systematic risk and idiosyncratic risk decrease due to the presence of independence board directors. In the banking sector, some studies (Mishra and Nielsen, 2000; Cornett et al., 2009) show that independent boards are essential for banking since it may help to develop income quality and compensation to the CEOs. Last, is the loan ratio. Lin and Zhang (2009) show that a loan ratio represents a bank's plan on intermediation actions. Banks which obtain low loan ratio may obtain diversification advantage (De Young and Roland, 2011) while banks with high loan ratio are more open to credit risks; therefore, they obtain higher risk. These dependent, independent, and control variables for the impact of board's diversity on a firm's performance and risk are summarized in Table 1. 
Table 1. Definitions and Sources for the Variables Used

\begin{tabular}{|c|c|c|}
\hline & Definitions / Calculations & Source \\
\hline \multicolumn{3}{|l|}{ Dependent Variables } \\
\hline ROA & Net Income / Total Assets & Bankscope / Annual Report \\
\hline ROE & Net Income / Total Equity & Bankscope / Annual Report \\
\hline SDROA & Standard Deviation of ROA & Bankscope / Annual Report \\
\hline SDROE & Standard Deviation of ROE & Bankscope / Annual Report \\
\hline ZSA & ROA divided by SDROA & Bankscope / Annual Report \\
\hline ZSL & EA (EA=Equity/Total Assets) divided by SDROA & Bankscope / Annual Report \\
\hline \multicolumn{3}{|c|}{ Independent Variables } \\
\hline $\begin{array}{l}\text { Nationality } \\
\text { Diversity }\end{array}$ & FID Indicator ( 1 if company has foreign directors, 0 otherwise) & Spencer Stuart \\
\hline Gender Diversity & Total number of female directors divided by total number of board directors & Spencer Stuart \\
\hline \multicolumn{3}{|l|}{ Control Variables } \\
\hline Firm Size & Logarithm of Total Assets & Bankscope / Annual Report \\
\hline Board Size & Logarithm of total number of board directors & Spencer Stuart \\
\hline Board Independent & Total number of board independence divided by total number of board directors & Spencer Stuart \\
\hline Loan Ratio & Loan divided by total assets ratio & Bankscope / Annual Report \\
\hline
\end{tabular}

\section{Empirical Results And Discussions}

\subsection{Descriptive Statistics}

Table 2 presents the descriptive statistics for the variables in the study. Panel B describes the board diversity measurement, which are nationality and gender diversity. The average percentage of foreign directors in Indian banking industry is 0.036 which is lower compared to previous studies which are conducted in developed countries (Masulis et al., 2012; Garcia-Meca et al., 2015; Estélyi, et al, 2016) and in emerging markets (Darmadi, 2011; Kilic, 2015). It indicates that from 22 banks in the sample, 3.63\% have one or more foreign directors in Indian banking industry. Meanwhile, the gender diversity is 0.071 , which is lower compared to earlier researches in developed countries by Garcia-Meca et al. (2015) and Estélyi, et al (2016) and Darmadi (2011) and Kilic (2015) in developing countries. It shows that the average percentage of female directors in Indian banking industry is $7.1 \%$. It can be seen that the diversity in gender is higher compared to the existence of foreign directors due to the implementation of Clause 149 in Companies Act 2013 that requires companies in India to involve at least one woman in their boards. These results indicate that the board diversity in India in terms of nationality and gender are still low compared to other developing countries such as Indonesia (Darmadi, 2011) and Turkey (Kilic, 2015).

Table 2. Descriptive Statistics

\begin{tabular}{|c|c|c|c|c|c|c|}
\hline & $\mathbf{N}$ & Mean & Median & Standard Deviation & Min & Max \\
\hline \multicolumn{7}{|c|}{ Panel A. Firm Performance and Risk } \\
\hline ROA & 110 & 0.016 & 0.015 & 0.009 & 0.003 & 0.038 \\
\hline ROE & 110 & 0.151 & 0.155 & 0.046 & 0.037 & 0.249 \\
\hline Standard Deviation of ROA & 110 & 0.002 & 0.002 & 0.002 & 0.000 & 0.019 \\
\hline Standard Deviation of ROE & 110 & 0.021 & 0.018 & 0.012 & 0.005 & 0.070 \\
\hline ZSA & 110 & 10.373 & 8.307 & 7.191 & 0.498 & 35.137 \\
\hline ZSL & 110 & 66.945 & 56.843 & 41.015 & 13.383 & 246.324 \\
\hline \multicolumn{7}{|c|}{ Panel B. Board Diversity Measurement } \\
\hline Nationality Diversity & 110 & 0.036 & 0.000 & 0.188 & 0.000 & 1.000 \\
\hline Gender Diversity & 110 & 0.071 & 0.074 & 0.068 & 0.000 & 0.250 \\
\hline \multicolumn{7}{|l|}{ Panel C. Control Variables } \\
\hline Firm Size & 110 & 23.973 & 24.141 & 1.208 & 20.969 & 26.727 \\
\hline Loan Ratio & 110 & 0.892 & 0.908 & 0.056 & 0.663 & 0.950 \\
\hline Board Size & 110 & 2.286 & 2.303 & 0.303 & 1.099 & 2.773 \\
\hline Board Independent & 110 & 0.595 & 0.577 & 0.121 & 0.000 & 0.833 \\
\hline
\end{tabular}




\subsection{Multivariate Analysis}

\subsubsection{Impact of Board Diversity on Bank Performance}

In generating the regression, this study uses the pooled panel since the data consist of cross-section and time series. Table 3 reports the regression of pooled panel for measuring the impact of the board diversity in terms of nationality and gender diversity to the firm's performance (ROA and ROE). It is clearly seen that the nationality diversity has significant and negative relationship with the bank performance in terms of both ROA and ROE. It indicates that if the number of foreign directors increases, the firm's performance worsens. This result is in line with the previous studies conducted by Masulis et al. (2012), Forbes and Miliken (1999) and Ruigrok, W. et al. (2007) which show that the presence of foreign directors leads to worse performance due to the distance problem, inability to obtain latest information, and communication problems that might result in conflicts. It is also in line with the researches that are conducted in banking industries: Garcia-Meca et al. (2015) in European banking industries, Kilic (2015) in Turkey, Setiyono and Tarazi (2014) in Indonesia. Second, the impact of gender diversity is calculated using the number of female directors divided by the total number of board directors. The results show that there is no significant impact of the presence of female directors to the company's performance in the proxies of ROA and ROE. These are in line with the studies by Terjesen and Singh (2008) that explains female directors have little influence to the firm performance. Again, regulation of Clause 149 that requires firms in India to appoint at least one woman in their boards mentioned in section 2.5 might be the cause why banks in India appoint women. These are also in accordance to the previous studies conducted in emerging markets by Kusumastuti et al. (2007) in Indonesia, Marimuthi, M. \& Kolandaisamy, I. (2009) in Malaysia, and Sitthipongpanich, T. \& Polsiri, P, 2013 in Thailand, in measuring the impact to the firm's value.

Table 3. Regression Result for Firm's Performance

\begin{tabular}{|c|c|c|c|c|}
\hline Variable & $R O A$ & $R O A$ & $R O E$ & $R O E$ \\
\hline \multirow[t]{2}{*}{$\mathbf{C}$} & $0.142 * * *$ & $0.135 * * *$ & $0.424 * * *$ & $0.366^{* *}$ \\
\hline & $(6.913)$ & $(6.263)$ & $(2.870)$ & $(2.296)$ \\
\hline \multirow[t]{2}{*}{ Firm Size } & $-0.003 * * *$ & $-0.002 * * *$ & $-0.027 * * *$ & $-0.023 * * *$ \\
\hline & $(-3.824)$ & $(-2.710)$ & $(-4.335)$ & $(-3.355)$ \\
\hline \multirow{2}{*}{ Loan Ratio } & $-0.064 * * *$ & $-0.076 * * *$ & $0.396 * * *$ & $0.334 * *$ \\
\hline & $(-3.325)$ & $(-3.893)$ & $(2.683)$ & $(2.197)$ \\
\hline \multirow[t]{2}{*}{ Board Size } & 0.001 & 0.003 & 0.007 & 0.015 \\
\hline & $(0.568)$ & (1.297) & $(0.434)$ & $(0.847)$ \\
\hline \multirow[t]{2}{*}{ Board Independent } & 0.000 & -0.002 & 0.027 & 0.014 \\
\hline & $(0.142)$ & $(-0.470)$ & $(0.864)$ & $(0.429)$ \\
\hline \multirow[t]{2}{*}{ Nationality Diversity } & $-0.007 * * *$ & & $-0.034 *$ & \\
\hline & $(-3.480)$ & & $(-1.901)$ & \\
\hline \multirow[t]{2}{*}{ Gender Diversity } & & -0.007 & & -0.079 \\
\hline & & $(-1.246$ & & $(-1.571)$ \\
\hline Obs. & 110 & 110 & 110 & 110 \\
\hline F-Statistics & 10.944 & 8.549 & 4.520 & 4.273 \\
\hline $\mathbf{R} 2$ & 0.345 & 0.291 & 0.179 & 0.170 \\
\hline Adj. R2 & 0.313 & 0.257 & 0.139 & 0.131 \\
\hline
\end{tabular}




\subsubsection{Impact of Board Diversity on Bank Risk}

The results show that there is positive and significant impact of the occurrence of foreign board directors to the risk taking in Indian banking industries in the measurement of ZSA and ZSL. These results are in line with previous studies conducted by Setiyono and Tarazi (2014) who find that the presence of foreign directors lead to a higher risk taking. The firm's size shows that there is positive and significant impact in the case of SDROE and ZSL, indicating that as the firm size in getting larger, they may take more risks. This might be due to their ability in generating more profits therefore having the courage to take more risks.

Second, in the measurement of gender diversity, the results show that only ZSA has positive and significant impact (at 10\% significance level) of the existence of women directors to the risk taking. The result might be caused by the lack of experience female directors have, supported by the fact of Clause 149 that require at least one woman to sit in board of directors. This result shows contrary findings compared to the previous studies (Barber and Odean, 2001; Jianakoplos and Bernasek, 1998; Mateos de Cabo et. al, 2012; Setiyono and Tarazi 2014) which find a negative relationship.

Table 4. Regression Result for Firm Risk of 4 years behind

The Dependent Variables are Standard Deviation of ROA (SDROA), Standard Deviation of ROE (SDROE), Z-Score of Asset Risk (ZSA) and Z-Score of Leverage Risk (ZSL). The sample consists of 22 companies in 5 years, start from 2011 until 2015. T-Statistics are stated within parentheses. Significance at 1,5 and 10 percent level has been indicated by $* * *, * *$ and *, respectively.

\begin{tabular}{|c|c|c|c|c|c|c|c|c|}
\hline Variables & $S D R O A$ & $S D R O A$ & SDROE & SDROE & $Z S A$ & $Z S A$ & $Z S L$ & $Z S L$ \\
\hline \multirow[t]{2}{*}{ C } & 0.030 & 0.032 & $-0.291 * *$ & -0.262 & -8.764 & 1.122 & -532.162 & -455.574 \\
\hline & (1.368) & (1.381) & $(-2.075)$ & $(-1.776)$ & $(-0.407)$ & $(0.050)$ & $(-1.275)$ & $(-1.022)$ \\
\hline \multirow[t]{2}{*}{ Firm Size } & $-0.002 * * *$ & $-0.002 * * *$ & $0.012 * * *$ & $0.011 * *$ & 0.662 & -0.084 & $41.356^{* * *}$ & $35.102 * * *$ \\
\hline & $(-3.605)$ & $(-3.378)$ & (3.091) & (2.539) & $(0.647)$ & $(-0.079)$ & $(3.568)$ & $(2.680)$ \\
\hline \multirow[t]{2}{*}{ Loan Ratio } & 0.029 & $0.029 *$ & 0.031 & 0.025 & -3.164 & 7.250 & -536.363 & -442.250 \\
\hline & (1.659) & (1.709) & $(0.281)$ & $(0.224)$ & $(-0.137)$ & $(0.314)$ & $(-1.614)$ & $(-1.329)$ \\
\hline \multirow[t]{2}{*}{ Board Size } & 0.000 & 0.000 & -0.007 & -0.007 & 0.392 & -1.328 & 31.251 & 22.200 \\
\hline & $(0.045)$ & $(-0.005)$ & $(-0.869)$ & $(-0.862)$ & $(0.129)$ & $(-0.436)$ & (1.273) & $(0.904)$ \\
\hline \multirow[t]{2}{*}{$\begin{array}{l}\text { Board } \\
\text { Independent }\end{array}$} & -0.002 & -0.002 & 0.019 & 0.020 & 8.260 & $11.140^{*}$ & 22.235 & 35.311 \\
\hline & $(-0.818)$ & $(-0.745)$ & $(1.405)$ & $(1.462)$ & (1.404) & (1.859) & $(0.555)$ & $(0.861)$ \\
\hline \multirow[t]{2}{*}{$\begin{array}{l}\text { Nationality } \\
\text { Diversity }\end{array}$} & 0.000 & & -0.002 & & $7.873 * *$ & & $40.136^{*}$ & \\
\hline & $(0.191)$ & & $(-0.293)$ & & $(2.241)$ & & $(1.803)$ & \\
\hline \multirow[t]{2}{*}{$\begin{array}{l}\text { Gender } \\
\text { Diversity }\end{array}$} & & 0.001 & & 0.013 & & $16.851^{*}$ & & 53.256 \\
\hline & & $(0.282)$ & & $(0.591)$ & & $(1.742)$ & & $(0.808)$ \\
\hline Obs. & 110 & 110 & 110 & 110 & 110 & 110 & 110 & 110 \\
\hline F-Statistics & 6.663 & 6.668 & 2.342 & 2.360 & 1.573 & 1.199 & 4.442 & 4.212 \\
\hline $\mathbf{R 2}$ & 0.676 & 0.676 & 0.423 & 0.425 & 0.070 & 0.055 & 0.582 & 0.569 \\
\hline Adjusted R2 & 0.575 & 0.575 & 0.243 & 0.245 & 0.026 & 0.009 & 0.451 & 0.434 \\
\hline
\end{tabular}




\subsection{Robustness Checks}

To check the robustness, we apply some models: (1) using alternative measurements of the bank performance (NIM and OEOI), (2) excluding the control variables, (3) using 2 periods in measuring the bank risk. Following the study of Setiyono and Tarazi (2014) who applied Net Interest Margin (NIM) and Ratio of Operating Expense to Operating Income (OEOI) as the alternative measurements for a bank performance. It is mentioned that both ratios have been regularly applied to estimate the performance of a bank (Setiyono and Tarazi, 2014). The results explain that the presence of foreign board directors lead to a lower performance of the company in a significant level of $1 \%$ with respect to NIM. This result is in line with the measurement of the firm's performance using both ROA and ROE presented in table 3. When measuring the performance of the financial institution using ROA and ROE, there is no significant impact of the existence of women directors; however, by using the alternative measure of OEOI, the result indicates that the female who sit in the board of directors are found to increase the performance of banking in India but only in the significance of $10 \%$. This result is in line with the previous research conducted by Erhardt et al. (2003). The positive relationship between the firm's performance and gender diversity may be generated by the action of female directors who do more monitoring to the operation of the firm compared to the male ones. In addition, the regression is done by excluding all of the control variables (firm size, loan ratio, board size, and board independent) to check whether the results presented in table 3 and 4 are caused by endogeneity. After excluding all of the control variables, the results show that both nationality and gender diversity are significant and have a negative relationship with regard to the ROA and ROE. Compared to the findings on table 3 which measure the impact of the board's diversity to the company's performance by including the control variables, it is clearly seen that nationality diversity performs the same result, indicating that the result in this variable is not triggered by endogeneity. In contrast, the outcome on gender diversity is different from the previous result in table 5; thus, it can be concluded that this variable is affected by endogeneity. While in the case of bank risk, the result shows that nationality diversity has positive relationship with risk taking in the case of ZSA and gender diversity has positive and significant relationship with the risk in the measurement of ZSL. These results are in line with the results in table 4 when control variables are included. Therefore, it can be concluded that those variables are not affected by endogeneity.Last method is by calculating the standard deviation of ROA and ROE based on two periods: the first 3 years (2010-2012) and the second 3 years (2013-2015). The results on the first 3 years indicate that there is no significant impact of both nationality and gender diversity to the risk taking in the Indian banking industry. While the results on the second 3 years show that the nationality diversity is found to have a mixed impact on companies' risk taking. In the measurement of ZSA and ZSL, it is found to have positive relationship, while SDROA shows a negative relationship among them. While, the existence of women directors is found to lead the company to take less risks. This result is in line with the previous studies conducted by Barber and Odean, (2001); Jianakoplos and Bernasek, (1998); Mateos de Cabo et. al, (2012) and Setiyono and Tarazi (2014). The negative relationship might be due to the characteristics of women as risk-averse, therefore having the tendency to take less risk to avoid failure.

\section{Conclusion}

This study focuses on 2 diversities: nationality and gender diversity which focuses on 22 banks and financial institutions in India from the period of $2011-2015$, resulting in a total of 110 . The presence of foreign directors are found to lead the company into worse performance which might be caused by the difficulties in doing the regular checking and the communication problems as the previous studies conducted by Masulis et al. (2012) and Forbes and Miliken (1999). While the existence of female directors is found to have no impact on the company's performance. This result might be explained by the fact that the inclusion of women directors is only to follow the regulation of Clause 149 in India that requires Indian firms to place at least one woman in their boards. The next concern in this study is to look for the effect of board diversities to the firm risks. The results show that the presence of both foreign directors and female board directors lead to a higher risk taking. The result on the impact of gender diversity to the firm risk is quite surprising as most of the previous studies found negative relationship among them. This might be due to the lack of experience of women as board directors that might result in a higher risk taking. Further, the outcomes of the robustness testing done indicate a consistent result of the negative effect of nationality diversity to the firm's performance whereas the gender diversity shows mixed impact on firm performance. In relation to the firm risk, by excluding the control variables and applying 2 period of times, there 
are varied results regarding the presence of FIDs and the inclusion of women directors. Overall, the results on the main regression and robustness testing indicate that both nationality and gender diversity play an important role to the performance and risk taking of the banking industry, supporting the findings of Setiyono and Tarazi (2014) and Claessens and Yortuglo (2013). By looking at this, the regulation in India should pay more attention to the inclusion of foreign and women directors in their board as the improvement of corporate governance in developing countries. There are some limitations in this study. First is the limited sample, as it only covers 22 banks and financial industries from the period 2011 - 2015 due to a lack of data on board profiles. Therefore, this study might not berepresentative for the financial institution in India. The other is that it only covers two kinds of board diversities: nationality and gender diversity while in fact there are still a lot of other diversities that could be observed, for instance age, education, experience, etc. Based on these constraints, future researches can be done to examine the impact of board diversities by comparing the performance of financial institutions vs non - financial institutions. As this research only focuses in India, there could be another study considering the performance of other densely-populated countries such as China and Indonesia, by also comparing their performances.

\section{References}

Adams, R., Ferreira, D. (2009), "Women in the boardroom and their impact on governance and performance", Journal of Financial Economics, Vol. 94, pp. 291-309. https://doi.org/10.1016/j.jfineco.2008.10.007

Adams, R.B., Hermalin, B.E., Weisbach, M.S. (2010), "The role of boards of directors in corporate governance: a conceptual framework \& survey", Journal of Economic Literature, Vol. 48, pp. 58-107. http://www.jstor.org/stable/40651578

Agnew, J., Balduzzi, P., Sunden, A. (2003), "Portfolio choice and trading in a large 401(K) plan”, American Economic Review, Vol. 93, pp. 193-215. https://www.aeaweb.org/articles?id=10.1257/000282803321455223

Ararat, M., Aksu, M., \& Cetin, A. T. (2010), “The impact of board diversity on boards' monitoring intensity and firm performance: evidence from the Istanbul Stock Exchange", Working paper, Sabanci University. https://papers.ssrn.com/sol3/papers.cfm?abstract id $=1572283$

Ashbaugh-Skaife, H., Collins, D.W., LaFond, R. (2006a), "The effects of corporate governance on firms' credit ratings", Journal of Accounting and Economics, Vol. 42, pp. 203-243. https://doi.org/10.1016/j.jacceco.2006.02.003

Ashbaugh-Skaife, H., Collins, D.W., LaFond, R. (2006b), “Corporate Governance, Risk and Cost of Equity Capital”, Working paper, University of Wisconsin, Madison. https://www.researchgate.net/profile/Daniel_Collins3/publication/251801513_Corporate_Governance_Risk_and_Cost_of_Equity/links/53fe2fla0cf21edafd15094f.pdf

Atkinson, S., Baird, S. and Frye, M. (2003), “Do female mutual fund managers manage differently?”, The Journal of Financial Research, Vol. XXVI No. 1, pp. 1-18. https://doi.org/10.1111/1475-6803.00041

Barber, B.M., Odean, T. (2001), "Boys will be boys: gender, overconfidence, and common stock investment”, The Quarterly Journal of Economics, Vol. 116, pp. 261-292. https://doi.org/10.1162/003355301556400

Berger, A.N. (1995), “The relationship between capital and earnings in banking”, Journal of Money, Credit and Banking, Vol. 27, pp. 432-456. http://www.jstor.org/stable/2077877

Berger, A.N., Kick T., Schaek, K. (2014), “Executive board composition and bank risk taking”, Journal of Corporate Finance, Vol. 28, pp. 48 - 65. https://doi.org/10.1016/j.jcorpfin.2013.11.006

Chandani, A., Mehta, M., \& Neeraja, B. (2014), "Women CEOs and financial performance of banks: An empirical research of Indian private sector banks", Journal of Contemporary Management Issues, Vol. 19(1), pp. 231-246. https://hrcak.srce.hr/124615

Cornett, M.M., McNutt, J., Tehranian, H. (2009), “Corporate governance and earnings management at large U.S. bank holding companies". Journal of Corporate Finance, Vol. 15, pp. 412-430. https://doi.org/10.1016/j.jcorpfin.2009.04.003

Darmadi, S. (2011). "Board diversity and firm performance: The Indonesian evidence". Corporate Ownership \& Control, 8(2-4), pp. 450-466. http://dx.doi.org/10.22495/cocv8i2c4p4

Davis, J.H., F.D. Schoorman, and L. Donaldson. (1997), "Toward a stewardship theory of management”, Academy of Management Review, Vol. 22, no. 1, pp. 20-47. http://www.jstor.org/stable/259223

Davydenko, V.; Kaźmierczyk, J.; Romashkina, G. F.; Żelichowska, E. 2017. "Diversity of employee incentives from the perspective 
of banks employees in Poland - empirical approach". Entrepreneurship and Sustainability Issues, Vol. 5, no 1, pp. 116-126. https://doi. org/10.9770/jesi.2017.5.1(9)

De Andrés, P., \& Vallelado, E. (2008), “Corporate governance in banking: The role of the board of directors", Journal of Banking \& Finance, Vol. 32(12), pp. 2570-2580. https://doi.org/10.1016/j.jbankfin.2008.05.008

De Nicolo, G. (2000), "Size, charter value and risk in banking: an international perspective", International Finance Discussion Papers. https://www.federalreserve.gov/pubs/ifdp/2000/689/default.htm

De Young, R., Roland, K.P. (2001), "Product mix and earnings volatility at commercial banks: Evidence from a degree of total leverage model", Journal of Financial Intermediation, Vol. 10, pp. 54-84. https://doi.org/10.1006/jfin.2000.0305

Dharmwani, L. T. (2015), "Role of corporate governance in Indian banking sector", Indian Journal of Applied Research. https://www. worldwidejournals.com/indian-journal-of-applied-research-(IJAR)/file.php?val=October_2015_1492515458_122.pdf

El Mehdi, I. K. (2007), "Empirical evidence on corporate governance and corporate performance in Tunisia”, Corporate Governance: An International Review, Vol. 15(6), pp. 1429-1441. https://doi.org/10.1111/j.1467-8683.2007.00655.x

Erhardt, N., Werbel, J., Shrader, C. (2003), "Board of director diversity and firm financial performance", Corporate Governance: An International Review, Vol. 11, pp. 102-111. https://doi.org/10.1111/1467-8683.00011

Estélyi, K.S., Nisar, T.M. (2016), “Diverse boards: Why do firms get foreign nationals on their boards?”, Journal of Corporate Finance 39, 174-192. https://doi.org/10.1016/j.jcorpfin.2016.02.006

Forbes, D., Milliken, F. (1999, “Cognition and corporate governance: understanding boards of directors as strategic decision-making groups", The Academy of Management Review, Vol. 24, pp. 489-505. http://www.jstor.org/stable/259138

García-Meca, E., García-Sánchez, I., Martínez-Ferrero, J. (2015), "Board diversity and its effects on bank performance: an international analysis”, Journal of Banking \& Finance, Vol. 53, pp. 202-214. https://doi.org/10.1016/j.jbankfin.2014.12.002

Ghosh, S. (2006), "Do board characteristics affect corporate performance? Firm - level evidence for India", Applied Economic Letters, Vol. 13:7, pp. 432-443. https://doi.org/10.1080/13504850500398617

Giedraitis, A.; Stašys, R.; Skirpstaitè, R. (2017), "Management team development opportunities: a case of Lithuanian furniture company". Entrepreneurship and Sustainability Issues Vol. 5 no 2, pp. 212-222. https://doi.org/10.9770/jesi.2017.5.2(4)

Goodstein, J., Gautam, K., Boeker, W. (1994), "The effects of board size and diversity on strategic change”, Strategic Management Journal, Vol. 15, pp. 241-250. http://www.jstor.org/stable/2486969

Graham, J.R., Harvey, C.R. and Puri, M. (2010), “Managerial attitudes and corporate actions”, Journal of Financial Economics, Vol. 109 (1), 103-121. https://doi.org/10.1016/j.jfineco.2013.01.010

Hagendorff, J., Collins, M., Keasey, K. (2007), "Bank governance and acquisition performance”, Corporate Governance: An International Review, Vol. 15, pp. 957-968. https://doi.org/10.1111/j.1467-8683.2007.00601.x

Haldar, A., Shah, R., \& Nageswara Rao, S.V.D. (2015), Gender diversity in large listed Indian companies. Corporate Ownership \& Control, Vol. 12 (3-5), pp. 573-580. http://doi.org/10.22495/cocv12i3c5p8

Hillman, A.J., A.A. Canella, and R.L. Paetzold. (2000), "Resource dependency role of corporate directors: strategic adaptation of board composition in response to environmental change", Journal of Management Studies, Vol. 37 no. 2, pp. 235-255. https://doi. org/10.1111/1467-6486.00179

in Indonesia since the 1997/ 1998 financial crisis?', Research In International Business and Finance, Vol. 32, pp.139-158. https://doi. org/10.1016/j.ribaf.2014.04.001

Jensen, M., Meckling, W. (1976), “Theory of the firm: managerial behavior, agency costs and ownership structure”, Journal of Financial Economics, Vol. 3, pp. 305-360. https://doi.org/10.1016/0304-405X(76)90026-X

Jhunjhunwala, S. and Mishra, R. K. (2012), "Board diversity and corporate performance: the Indian evidence", The IUP Journal of Corporate Governance, Vol. XI, No. 3, July 2012, pp. 71-79. https://papers.ssrn.com/sol3/papers.cfm?abstract_id=2173107

Jianakoplos, N.A., Bernasek, A. (1998), “Are women more risk averse?”, Economic Inquiry, Vol. 36, pp. 620-630. https://doi. org/10.1111/j.1465-7295.1998.tb01740.x

Jindal, V. and Jaiswall, M. (2015), "Board diversity and firm performance influenced by ownership concentration: evidence from India", Working Paper Series No. 765. http://financelab.iimcal.ac.in/wp-content/uploads/2017/09/WPS-765.pdf 
Johnson, J.L., C.M. Daily, and A.E. Ellstrand. (1996), "Boards of directors: a review and research agenda", Journal of Management, Vol. 22, pp. no. 3: 409-438. https://doi.org/10.1016/S0149-2063(96)90031-8

Jurevičienè, D.; Skvarciany, V. (2016), Camels+t approach for banks' assessment: evidence from the Baltics. Entrepreneurship and Sustainability Issues Vol. 4 no 2, pp. 159-173. https://doi.org/10.9770/jesi.2016.4.2(4)

Kanagaretnam, K., Lim, C.Y. and Lobo, G.J. (2011), “Effects of national culture on earnings quality of banks", Journal of International Business Studies, Vol. 42, No. 6, pp. 853-74. http://www.jstor.org/stable/29789463

Kilic, M. (2015), “The effect of board diversity on the performance of banks: evidence from Turkey", International Journal of Business and Management, Vol 10, No. 9. http://dx.doi.org/10.5539/ijbm.v10n9p182

Kusumastuti, S., Supatmi, and Sastra, P. (2007), "Pengaruh board diversity terhadap nilai perusahaan dalam perspektif corporate governance”, Jurnal Akuntansi dan Keuangan, Vol. 9 No. 2, pp. 88-98. https://doi.org/10.9744/jak.9.2.pp.\%2088-98

Laeven, L. and Ross L. (2009), “Bank governance, regulation and risk taking”, Journal of Financial Economics, Vol. 93, pp. $259-75$. https://doi.org/10.1016/j.jfineco.2008.09.003

Luhn, A.; Aslanyan, S.; Leopoldseder, C.; Priess, P. (2017), “An evaluation of knowledge management system's components and its financial and non-financial implications". Entrepreneurship and Sustainability Issues Vol. 5 no 2, pp. 315-329. https://doi.org/10.9770/ jesi.2017.5.2(11)

Lynall, M.D., B.R. Golden, and A.J. Hillman. (2003), "Board composition from adolescence to maturity: a multitheoretic view", Academy of Management Review, Vol. 28, no. 3, pp. 416-431. http://www.jstor.org/stable/30040730

Marimuthu, M., Kolandaisamy, I. (2009), "Ethnic and gender diversity in boards of directors and their relevance to financial performance of Malaysian companies", Journal of Sustainable Development, Vol. 2 No. 3, 139-148. http://dx.doi.org/10.5539/jsd.v2n3p139

Masulis, R., Wang, C., Xie, F. (2012), "Globalizing the boardroom - the effects of foreign directors on corporate governance and firm performance", Journal of Accounting and Economics, Vol. 53, pp. 527-554. https://doi.org/10.1016/j.jacceco.2011.12.003

Mateos de Cabo, R., Gimeno, R., Nieto, M. (2012), “Gender diversity on European banks' boards of directors”, Journal of Business Ethics, Vol. 109, pp. 145-162. https://link.springer.com/article/10.1007/s10551-011-1112-6

Maxfield, S., Shapiro, M., Gupta, V. and Hass, S. (2010), "Gender and risk: women, risk taking and risk aversion”, Gender in Management: An International Journal, Vol. 25 No. 7, pp. 586-604. https://www.emeraldinsight.com/doi/abs/10.1108/17542411011081383

Maznevski, M. (1994), "Understanding our differences: performance in decision-making groups with diverse members", Human Relations, Vol. 47, pp. 531-552. http://journals.sagepub.com/doi/abs/10.1177/001872679404700504

Mihet, R. (2012), "Effects of culture on firm risk taking: a cross - country and cross - industry analysis", International Monetary Fund, WP/12/210. https:/www.imf.org/en/Publications/WP/Issues/2016/12/31/Effects-of-Culture-on-Firm-Risk-Taking-A-Cross-Countryand-Cross-Industry-Analysis-26204

Miletkov, M., Poulsen, A., Wintoki, M.B. (2014), “A multinational study of foreign directors on non-U.S. corporate boards”, Working paper, University of New Hampshire. https://www.researchgate.net/publication/256015910_A_Multinational_Study_of_Foreign_Directors_on_Non-US_Corporate_Boards

Mishra, C.S., Nielsen, J.F. (2000), "Board independence and compensation policies in large bank holding companies”, Financial Management, Vol. 29, pp. 51-70. http://www.jstor.org/stable/3666229

Mizruchi, M.S., and L.B. Stearns. (1988), "A longitudinal study of the formation of interlocking directorates”, Administrative Science Quarterly, Vol. 33, no. 2, pp. 194-210. http://www.jstor.org/stable/2393055

Niederle, M., Vesterlund, L. (2005), “Do women shy away from competition? Do men compete too much?”, Quarterly Journal of Economics, Vol. 122, pp. 1067-1101. https://doi.org/10.1162/qjec.122.3.1067

Nys, E., Tarazi, A., Trinugroho, I. (2015). "Political connections, bank deposits, and formal deposit insurance." Journal of Financial Stability 19, 83-104. https://doi.org/10.1016/j.jfs.2015.01.004

Oxelheim, L., Randøy, T. (2013), "Globalization of monitoring practices: the American influence on dismissal performance sensitivity of European CEOs”, Journal of Economic and Business, Vol. 70, pp. 3-15. https://doi.org/10.1016/j.jeconbus.2013.02.002

Pathan, S., \& Faff, R. (2013), “Does board structure in banks really affect their performance?”, Journal of Banking \& Finance, Vol. 37(5), pp. 1573-1589. https://doi.org/10.1016/j.jbankfin.2012.12.016 
Ramasmawy, K. and Li, M. (2001), "Foreign investors, foreign directors and corporate diversification: an empirical examination of large manufacturing companies in India”, Asia Pacific Journal of Management, Vol. 18, pp. 207-222. https://link.springer.com/article/ 10.1023/A:1010620008101

Raudeliūnienė, J.; Davidavičienè, V.; Jakubavičius, A. (2018), “Knowledge management process model”. Entrepreneurship and Sustainability Issues Vol 5 no 3, pp. 542-554. https://doi.org/10.9770/jesi.2018.5.3(10)

Rosha, A.; Lace, N. (2018), "Relevance analysis of factors enhancing coaching interactions in organizations". Entrepreneurship and Sustainability Issues Vol 5 no 3, pp. 480-492. https://doi.org/10.9770/jesi.2018.5.3(5)

Rost, K., Osterloh, M. (2010), “Opening the black box of upper echelons: drivers of poor information processing during the financial crisis”, Corporate Governance: An International Review, Vol. 18, pp. 212-233. https://doi.org/10.1111/j.1467-8683.2010.00796.x

Ruigrok, W., Peck, S., Tacheva, S. (2007), "Nationality and gender diversity on Swiss corporate boards", Corporate Governance: An International Review, Vol. 15, pp. 546-557. https://doi.org/10.1111/j.1467-8683.2007.00587.x

Sarkar, J., and Selarka, E. (2015), "Women on board and performance of family firms: Evidence from India”, Indira Gandhi Institute of Development Research. http://www.igidr.ac.in/pdf/publication/WP-2015-026.pdf

Schubert, R. (2006), "Analyzing and managing risks - on the importance of gender difference in risk attitudes", Managerial Finance, Vol. 32 No. 9, pp. 706-715. https://www.emeraldinsight.com/doi/abs/10.1108/03074350610681925

Schwizer, P., Soana, M. G., \& Cucinelli, D. (2012), “The relationship between board diversity and firm performance: The Italian evidence", Working paper, Department of Banking and Insurance, Faculty of Economics, University of Parma. https://iris.unibocconi.it/ handle/11565/3833302

Setiyono, B., Tarazi, A. (2014), “Does diversity of board members affect performance and risk?”, Evidence from an emerging market. HAL, 01070988. https://hal-unilim.archives-ouvertes.fr/hal-01070988/document

Sitthipongpanich, T., Polsiri, P. (2013), “Who's on Board? Influence of Diversity and Network of Thai Boards of Directors on Firm Value", The Journal of Applied Business Research, Volume 29, number 6, pp. 1763-1780. http://dx.doi.org/10.19030/jabr.v29i6.8213

Sokól, A.; Figurska, I. (2017), "Creativity as one of the core competencies of studying knowledge workers". Entrepreneurship and Sustainability Issues Vol. 5 no 1, pp. 23-35. https://doi.org/10.9770/jesi.2017.5.1(2)

Sunden, A., Surette, B. (1998), "Gender differences in the allocation of assets in retirement savings plans", American Economic Review, Vol. 88, pp. 207-211. http://www.jstor.org/stable/116920

Terjesen, S., Singh, V. (2008), "Female presence on corporate boards: A multi-country study of environmental context”, Journal of Business Ethics, Vol. 83, pp. 55-63. https://link.springer.com/article/10.1007/s10551-007-9656-1

Trinugroho, I., Agusman, A. and Tarazi, A. (2014) 'Why have bank interest margins been so high in Indonesia since the $1997 / 1998$ financial crisis?', Research In International Business and Finance, Vol. 32, pp.139-158. https://doi.org/10.1016/j.ribaf.2014.04.001

Trinugroho, I., Risfandy, T., Ariefianto, M.D., Prabowo, M.A., Purnomo, H., Purwaningsih, Y. (2017), “Does Religiosity Matter for Islamic Banks' Performance? Evidence from Indonesia.” International Journal of Economics and Management 11(2), pp. 419- 435.nhttp://www. ijem.upm.edu.my/vol11_no2/(8)DOES\%20RELIGIOSITY\%20MATTER\%20FOR\%20ISLAMIC\%20BANKS\%E2\%80\%99\%20 PERFORMANCE\%20EVIDENCE\%20FROM\%20INDONESIA.pdf

Tse, D.K., Lee, K., Vertinsky, I. and Wehrung, D.A. (1988), "Does culture matter? a cross-cultural study of executives choice, decisiveness, and risk adjustment in international marketing", Journal of Marketing, Vol. 52, pp. 181-95. http://www.jstor.org/stable/1251635

Wachudi, E.J., Mboya J. (2012), "Effect of board gender diversity on the performance of commercial banks in Kenya", European Scientific Journal, Vol. 8, No. 7. https://eujournal.org/index.php/esj/article/view/120

Wang, C-J. (2012), “Board size and firm risk-taking”, Review of Quantitative Finance and Accounting, Vol. 38 No. 4, pp. 519-542. https://link.springer.com/article/10.1007/s11156-011-0241-4

Wiersema, M.F., Bantel, K.A. (1992), "Top management demography and corporate strategic change”, The Academy of Management Journal, Vol. 35, pp. 91-121. http://www.jstor.org/stable/256474

Włodarczyk, B.; Szturo, M.; Ionescu, G. H.; Firoiu, D.; Pirvu, R.; Badircea, R. 2018. "The impact of credit availability on small and medium companies," Entrepreneurship and Sustainability Issues Vol. 5 no 3, pp. 565-580. https://doi.org/10.9770/jesi.2018.5.3(12) 